\title{
Elderly and drugs: risks and necessity of rational use
}

\author{
André de Oliveira Baldoni ${ }^{1, *}$, Farah Maria Drumond Chequer ${ }^{2}$, Elisa Raquel Anastácio Ferraz ${ }^{2}$, \\ Danielle Palma de Oliveira ${ }^{2}$, Leonardo Régis Leira Pereira ${ }^{1}$, Daniel Junqueira Dorta ${ }^{3}$
}

\begin{abstract}
${ }^{1}$ Department of Pharmaceutical Sciences, Faculty of Pharmaceutical Sciences of Ribeirão Preto, University of São Paulo, ${ }^{2}$ Department of Clinical, Toxicological and Bromatological Analyses, Faculty of Pharmaceutical Sciences of Ribeirão Preto, University of São Paulo, ${ }^{3}$ Department of Chemistry, Faculty of Philosophy, Sciences and Letters of Ribeirão Preto, University of São Paulo
\end{abstract}

\begin{abstract}
In recent decades, the world has undergone a demographic transformation with a rapid growth of the elderly population, resulting in an increased demand for funds to maintain their health and drug consumption. Pharmacokinetic and pharmacodynamic changes occurring in the elderly can interfere directly in the adverse effects of drugs and increase the risk of intoxication. In addition, there are external factors interfering with the pharmacotherapy of the elderly, such as inappropriate use and the lack of access to information. Many therapeutic classes of drugs should be used with caution or avoided in the elderly population, such as anti-inflammatory and some anti-hypertensive drugs, diuretics and digitalis. If not managed carefully, these medicines can affect the safety and quality of life in the elderly. Thus, the aim of this review was to identify drugs that should be used with caution in elderly patients in order to avoid intoxication and/or adverse drug events.
\end{abstract}

Uniterms: Elderly/inappropriate medicines. Medicines/consumption. Medicines/adverse reaction. Medicines/intoxication. Medicine/rational use. Medicine/inappropriate prescribing.

Durante as últimas décadas, o mundo passou por uma transformação demográfica, com um rápido crescimento da população idosa e, portanto, tanto a demanda para a manutenção da saúde deste grupo populacional, quanto o consumo de medicamentos estão aumentando. Ainda, as mudanças farmacocinéticas e farmacodinâmicas que ocorrem em idosos podem interferir diretamente nos efeitos adversos dos medicamentos e aumentar o risco de intoxicação. Além disso, há fatores externos que interferem na farmacoterapia dos idosos, tais como o uso inadequado e a falta de acesso à informação. Existem várias classes terapêuticas de medicamentos que devem ser utilizados com cautela ou evitados na população idosa, tais como antiinflamatórios, alguns anti-hipertensivos, diuréticos, digitálicos entre outros. Estes medicamentos, se não forem utilizados com cuidado, podem afetar a qualidade de vida e a segurança desta população. Assim, este trabalho visa identificar medicamentos que devem ser utilizados com cuidado em pacientes idosos para evitar intoxicações e/ou eventos adversos aos medicamentos.

Unitermos: Idosos/medicamentos inadequados. Medicamentos/consumo. Medicamentos/reação adversa. Intoxicação medicamentosa. Medicamentos/uso racional. Prescrição inapropriada.

\section{INTRODUCTION}

\section{The elderly}

Despite the fact that drug consumption is an important issue in all age groups, this subject has been more

\footnotetext{
*Correspondence: A. O. Baldoni. Departamento de Ciências Farmacêuticas, Faculdade de Ciências Farmacêuticas de Ribeirão Preto, Universidade de São Paulo. Av. do Café, s/n - Campus Universitário - 14040-903 - Ribeirão Preto SP-Brasil. E-mail: andrebaldoni@yahoo.com.br
}

extensively studied amongst aged individuals, largely due to the structural and functional changes associated with the aging process (Nóbrega, Melo, Karnikowski, 2005). Generally, adverse drug reactions are observed 2 to 3 times more frequently in geriatric patients than in younger adults (Turnheim, 1998). This review deals with the principles of drug use in the elderly, and the age-related alterations in their pharmacokinetics and pharmacodynamics, as consequences of age-related changes occurring in the body's physiological functions. 
The percentage of the elderly population is increasing throughout the world as a result of an increased average lifespan, and due to this, the National Institute on Aging and the National Institute of Health, have redefined the term "elderly" as referring to the age group greater than or equal to 65 years old (Parker et al., 1997). However, in 1984 the World Health Organization defined the concept of elderly in a slightly different way, in a report from the Expert Group on Epidemiology and Aging. From a chronological point of view, the elderly group encompasses the population aged 60 years or older in developing countries, while in developed countries they have maintained the age of 65 years or older for the definition of elderly (WHO, 1984).

Elderly patients are characterized by age-specific problems such as multi-organ functional decline, alterations in mental status, depression, reduced nutritional status and the absence of social support, all of which have the potential to interfere with the pharmacotherapy of these patients. The biological age of the patient is one of the most important parameters and should be defined individually, based on co-morbidities and performance status (Balducci, Beghe, 2001).

Several factors contribute to the great number of adverse drug reactions that affect the elderly besides their high drug consumption (Castleden, Pickles, 1988). For example, they are more likely to suffer from chronic illness, so long-term use of medicine may increase the risk of adverse drug reactions (Ritz, Vellas, 2007). In addition, multiple health problems and polypharmacy (multiple drug usage) are common amongst the elderly population, which increases the probability of confusion during drug administration and the risk of interactions (Turnheim, 2004; Posner, 2009).

Another factor that leads to drug toxicity and Adverse Drug Reactions (ADRs) in elderly people is inappropriate administration of the medication. The study conducted by Aparasu and Mort (2004) found a high prevalence of elderly persons in the United States that received potentially inappropriate psychotropic medications. Moreover, Correr et al. (2007) evaluated the prescriptions and risks of drug-related problems in a geriatric institution, and found that $13.5 \%$ of the drugs used were considered inadequate, increasing the risk of problems with drugs, mainly concerning the safety of the therapy. Moreover, these authors identified 69 drug interactions in 38 patients $(51.3 \%)$, with events especially related to therapeutic effectiveness (Correr et al., 2007).

There are established criteria to determine inappropriate drugs for elderly usage, the most widely used being Beers's Criteria. These criteria, prepared by experts in the United States of America, contain an explicit list of 48 medicines or classes of drugs that should not be used in elderly patients, independent of the pathological condition, such as muscle relaxants and antispasmodics, some antidepressants, long-acting benzodiazepines, shortacting dipyridamole, methyldopa, clonidine, cimetidione and mineral oil, plus a list of 20 inappropriate drugs with specific pathological conditions, for example $\alpha$-Blockers for elderly patients with stress incontinence and calcium channel blockers for elderly patient with chronic constipation (Fick et al., 2003).

Another screening tool cited for use in identifying the potentially inappropriate prescribing of drugs for older people is the "Improving Prescribing in The Elderly" tool (IPET). This is a Canadian guideline including 14 instances of inappropriate prescribing and is a combination of explicit contraindications, and adverse drug-drug and adverse drug-disease interactions (Naugler et al., 2000). However, the guideline has not been as widely used as Beers criteria in published research studies.

Nevertheless, no explicit criteria covers all drugs that should be avoided or used with caution in this group of patients, but it is necessary to consider the implicit information about medications, and take into account the needs and circumstances of each patient in order to avoid ADRs and/or intoxication.

METHOD

The search for articles was carried out on the PubMed, Science Direct and Scielo databases. This survey was concerned with appropriate and inappropriate drugs for the elderly and/or compromise in the quality of life and safety of this patient group. The keywords used were "elderly", "drugs", "inappropriate prescribing", "adverse drug reaction" and "intoxication", and the articles included were in the English and Portuguese languages. After the search for articles, an analysis was carried out to select relevant articles from the title and abstract, with no limit on the date of publication of the articles.

\section{Pharmacokinetics in the elderly}

Age-related changes in the pharmacokinetics and pharmacodynamics of patients may cause an increase in ADRs in elderly people. In fact, aging causes a number of changes in drug absorption, distribution, biotransformation, and elimination (Galeotta et al., 1990).

The most important factors influencing drug absorption in the aged are: the rise in gastric $\mathrm{pH}$ because of a reduction in acid output due to a decrease in gastric parietal cells (Greenblatt, Sellers, Shader, 1982). This rise 
in gastric $\mathrm{pH}$ increases the absorption of basic drugs and reduces absorption of acid drugs, for example, antidepressants that are weakly basic are quickly absorbed in the intestine, which is weakly acid; the reduction in gastrointestinal motility, consequently delaying gastric emptying (Galeotta et al., 1990); the reduction in splanchnic blood flow due to diminished cardiac output (Safar, 1990); and the decrease in absorption surface (Gareri et al., 1998).

On the other hand, most drug absorption from the gastrointestinal tract is by passive diffusion and there is little evidence to suggest that there are significant agerelated changes in the amount of drug absorption, with one exception, levodope. The amount of levodope absorbed increases in the elderly because the dopa-decarboxylase levels in the gastric mucosa diminish with age, and therefore less levodopa is degraded in the stomach (Noble, 2003). Some substances (such as iron and calcium) that enter the bloodstream by active transport mechanisms are poorly absorbed in the elderly, where this effect can alter transport protein activity, and have other consequences that reshape drug absorption profiles among older patients (Turnheim, 2003). However, important changes are seen in the elderly when it comes to drug-drug interactions. For instance, antacids decrease the oral absorption of $\mathrm{H} 2$-antagonists (e.g., cimetidine and ranitidine), and alcohol accelerates the absorption of chloral hydrate (Noble, 2003).

The distribution of a drug is influenced by tissue blood flow, plasma protein binding and the physicochemical properties of the drug itself (Galeotta et al., 1990). Moreover, it is influenced by lean and non-lean body mass, total body water and extracellular volume (Kyle et al., 2001). Since adipose mass increases with aging, while total body water is reduced, the distribution volume is lower for water-soluble drugs and greater for lipid-soluble ones, such as verapamil, diazepam, nitrazepam, amytriptiline and amiodarone (Turnheim, 2003). Therefore these drugs tend to accumulate in the adipose tissue, and consequently their plasma half-life and their actions increase, thus causing the risk of adverse effects in the elderly (Greenblatt, Sellers, Shader, 1982; Furlanut, Benetello, 1990).

The body distribution of medications can be affected by changes in body composition and changes in protein binding. As stated above, the elderly usually have an increase in adipose tissue, decrease in lean body mass and reduction in total body water (Gareri et al., 1998). These alterations can cause significant changes in the volume distribution of various medications. For water-soluble drugs, the reduced volume distribution can increase the initial concentration in the central compartment, causing higher plasma concentrations, as in the case of cimetidine, digoxin, gentamicin and theophylline (Noble, 2003).
The elderly also tend to have decreased albumin and increased alpha1 acid glycoprotein levels, which can make the elderly more susceptible to acute effects of multiple drug therapy when highly protein-bound drugs are prescribed together. As the body ages, cardiac output is often reduced and peripheral vascular resistance increases, leading to a decrease in total systemic perfusion of the vital organs, including the kidneys and liver. This reduction in perfusion can decrease the body's ability to metabolize and excrete drugs (Cooney, Pascuzzi, 2009).

Changes in drug metabolism can elevate drug responses in elderly patients. There is a decrease in hepatic blood flow compared to a 25 year-old, resulting in a major reduction in the first-pass metabolism of the drugs. Medications subject to oxidative phase I metabolism exhibit decreased elimination, because phase I metabolism is catalyzed by the cytochrome P450 (CYP 450) system in the smooth endoplasmic reticulum of the hepatocytes, a process that diminishes with age (Cooney, Pascuzzi, 2009). Some antihypertensive medicines that are affected by this first-pass metabolism include propranolol, verapamil and nifedipine (Tanaka, 1998). Phase II metabolism, which involves the conjugation of a drug molecule by glucuronidation, acetylation or sulfation, is not generally affected by age. For example, if an antihypertensive drug listed above is prescribed to an elderly patient and taken together with a potent CYP 3A4 inhibitor, a potentially serious drug interaction can occur, leading to toxicity (O’Mahony, Woodhouse, 1994; Noble, 2003; Cooney, Pascuzzi, 2009).

Renal function progressively declines with advancing age. A reduction in renal plasma flow, renal tubular clearance and creatinine clearance, and an increase in serum creatinine occur in the elderly, due to their decline in muscle mass. Altered renal clearance leads to two clinically significant effects: prolonged half-lives of drugs; and an increase in their serum levels (Noble, 2003; Cooney, Pascuzzi, 2009). For drugs with a narrow therapeutic index (e.g. digoxin, cimetidine, aminoglycosides, warfarin), serious side effects may occur in older patients if appropriate dose reductions are not applied (Noble, 2003).

\section{Pharmacodynamics in the elderly}

In a review carried out by Williams and Lowenthal (1992), many changes in the pharmacodynamics of drugs in elderly patients were evidenced, due to alterations in the interactions between the drugs and receptors. Some drugs should be given with extreme caution to the elderly, for example warfarin, since it causes greater risk of hemorrhage in these patients, and they are also more sensitive to the 
effects of potent analgesics and benzodiazepines. On the other hand, the elderly are less sensitive to some of the cardiovascular effects of isoproterenol and propranolol. The alpha-adrenergic receptors have shown either no change or a decrease in the number and affinity of these receptors with age (Williams, Lowenthal, 1992).

\section{Pharmacotherapy in elderly patients}

The relationship between ageing and the organism's response to drugs has been further explored, studying the effects of the different classes of drugs in both old and young subjects.

\section{Central nervous system drugs}

The elderly are more sensitive to medications that affect the central nervous system function (Williams, Lowenthal, 1992). An overview of these is described further below.

\section{Benzodiazepines}

Psychopharmacological treatment is an integral part of the treatment for anxiety disorders. Benzodiazepines are the most commonly used psychotropic drugs amongst older people (Uchida, Mamo, 2009) and are widely used in older patients with anxiety disorders (Kirby et al., 1999; Uchida et al., 2009).

The adverse effects of benzodiazepine include dizziness, ataxia, drowsiness, and impairment of psychomotor function, and these effects appear to increase with age. The greater sedation and degree of psychomotor impairment in the elderly may be due to reduced clearance of the drug, and since it is lipid-soluble, also due to higher plasma concentrations (Greenblatt et al., 1991). Benzodiazepines with long-duration action (e.g. diazepam) are particularly likely to accumulate and therefore have a greater potential for sedative effects and psychomotor impairment (Kirby et al., 1999). Older people who are taking benzodiazepines with a long elimination half-life have been shown to have an increased risk of falls (Tinetti, Speechley, Ginter, 1988), a greater risk of hip fracture (Ray, Gri, Downey, 1989) and an increased chance of being involved in a motor vehicle crash (Hemmelgarn, Suissa, Huang, 1997).

Simon et al. (1996) reported that in 1992, the use of benzodiazepine increased with patient age among the members of a large United States health maintenance organization. Other studies carried out between 1989 and 1997 in a variety of Western countries reported that $10 \%-17 \%$ of elderly community residents used benzodiazepines (Kirb et al., 1999; Blazer et al., 2000). Moreover, Tu and colleagues (2001) reported that in 1993, about $25 \%$ of elderly individuals in the Canadian province of Ontario used benzodiazepines, whereas in 1998, approximately $23 \%$ used these medications. Thus the use of benzodiazepine, although declining, remained substantial amongst elderly Canadians.

It is known that the risks arise from the long-term use of benzodiazepine, and long-term users can develop withdrawal symptoms if benzodiazepines are discontinued abruptly (Schweizer, Rickels, 1998). Cognitive impairments indisputably occur with the acute administration of benzodiazepines, but the studies differ over the extent of cognitive impairments amongst long-term users. Some studies state continued cognitive difficulties with chronic use (Hanlon et al., 1998), whereas others report only modest impairments amongst healthy long-term users (McAndrews et al., 2003). Some evidence also suggests that chronic benzodiazepine use is linked to subsequent development of dementia (Paterniti et al., 2002).

Benzodiazepines are lipid soluble medications that have a prolonged half life in the elderly because of their accumulation in lipid tissue. Due to the extended duration of action and increased sensitivity to sedative hypnotics in the elderly, benzodiazepines can cause delirium (Alagiakrishnan, Wiens, 2004). According to Beers' criteria, the long-acting benzodiazepines should be avoided, and therefore short and intermediate-acting benzodiazepines are preferred in the elderly (Fick et al., 2003).

\section{Antidepressants}

Depression is a common disorder in the elderly. Estimations of the prevalence of major depressive disorder vary from $1 \%$ to $3 \%$ amongst the elderly (Mulsant, Ganguli, 1999). An additional $10 \%$ to $25 \%$ of the elderly show substantial depressive symptoms that do not meet the Diagnostic and Statistical Manual of Mental Disorders, Fourth Edition (DSM IV) criteria for major depression. Depression in the elderly has been associated with diminished quality of life, increased functional disability, increased use of health care resources, and poorer outcomes in patients with a variety of medical disorders (Kotlyar, Dysken, Adson, 2005).

It has been well documented in the literature that older adults metabolize pharmacological agents slower than younger adults, and are at greater risk for developing adverse side effects or acute toxic reactions, and are more likely to have multiple medical diseases that will need extra medications that may complicate the treatment with antidepressant medication (Teri et al., 1991). Data providing clinical recommendations for depressed elderly patients is limited, and consequently the treatment recom- 
mendations are usually based on data from younger patient populations or from small studies of elderly patients. In addition, the medically ill and the "oldest old" ( $>85$ years) are generally not included in clinical trials, and thus data regarding such patients is even more scarce. Finally, scant information is available regarding antidepressant efficacy in the most common mood disorders in elderly patients, such as dysthymic disorder, minor depression or mixed anxiety and depression (DasGupta, 1998).

\section{- Tricyclic Antidepressants (TCAs)}

For several decades, tricyclic antidepressants (TCAs) were considered the cornerstone of antidepressant therapy. Although TCAs are effective antidepressants, their adverse effect profile limits their use, for example, muscarinic receptor blockade results in several particularly troublesome adverse effects for elderly patients, such as dry mouth, sweating, tachycardia, urinary retention, blurred vision, postural hypotension and confusion. Another TCA effect is postural hypotension that may have severe consequences, such as sudden drops in blood pressure which increase the potential for hip fracture (high incidence femoral neck fracture), stroke or myocardial infarction (Halaris, 1987; Koenig, 1991; Gareri et al., 1998). A study of 1021 patients with hip fractures demonstrated a clear relationship between TCA therapy and its risk (DasGupta, 1998).

In addition, TCAs may cause arrhythmias, heart blocks (Jefferson, 1975) and slow atrioventricular conduction (Veith et al., 1982). TCA have important side effects in the central nervous system, more specifically, antimuscarinic effects such as xerostomy, constipation, paralytic ileus and urinary retention. Amitryptiline provokes sedation and exhibits strong anticholinergic properties (Fick et al., 2003). Imipramine shows an antiarrhythmic action and nortriptyline causes difficulty in falling sleep. Nortiptiline and desipramine appear to be the best tolerated tricyclics in older people. However, second generation antidepressants are preferred for the elderly and for those patients with heart disease, since they have milder side effects and are less toxic in terms of overdose (Gareri et al., 1998).

It is important to note that in elderly patients, all antidepressants can contribute to delirium. The tricyclic antidepressants have an anticholinergic effect and can induce delirium. Amongst the selective serotonin uptake inhibitors, paroxetine has the greatest affinity for muscaranic receptors, similar to nortriptyline (Richelson, 1993). Dopaminergic medications such as levodopa or dopamine agonists can contribute to delirium in a dose-related manner, and in elderly patients with dementia, lithium can cause delirium even at therapeutic serum levels (Brown,
Rosen, 1992). Meperidine (Demerol ${ }^{\circledR}$, pethidine) is often avoided in seniors due to its accumulation as a result of decreased renal function. Meperidine is converted to an anticholinergic metabolite that can cross the blood-brain barrier and lead to delirium (Alagiakrishnan, Wiens, 2004).

In patients with Dementia of the Alzheimer's type (DAT), the effects of medication are particularly worrisome. The anticholinergic effects of common antidepressants such as the TCAs, may serve to increase cognitive deficits in non-demented older adults, and patients with DAT already demonstrate loss of cholinergic neuronal function, so TCAs may exacerbate the cognitive impairment of DAT patients (Teri et al., 1991).

The symptoms of depression, apathy and fatigue, are common symptoms amongst medically-ill older adults and patients with advanced disease, and have been associated with morbidity and mortality. Methylphenidate has been used to treat these symptoms because of its rapid effect (Hardy, 2009).

\section{- Psychostimulants}

Since their introduction in the 1930s, psychostimulants such as amphetamine and methylphenidate have been used in the treatment of depression. Methylphenidate is a central nervous system stimulant approved by the US Food and Drug Administration (FDA) for the treatment of attention-deficit/hyperactivity disorder and narcolepsy (Sood, Barton, Loprinzi, 2006). Some studies have shown an increase in liver enzymes, and blood pressure alterations in older patients treated chronically with this drug (Hardy, 2009). Amphetamines and anorexic agents show a high potential for causing dependence, hypertension, angina and myocardial infarction, particularly in elderly patients (Fick et al., 2003).

\section{- Atypical antidepressants}

The atypical antidepressants are new molecules with the effects of tricyclic ones, only with far fewer side effects (Gareri et al., 1998). Of these, trazodone causes dizziness, drowsiness and especially orthostatic hypotension, while there are no antimuscarinic effects apart from xerostomy (Haria, Fitton, Mctavish, 1994). Bupropion, an aminoketone compound with 3 pharmacologically active metabolites, is an effective and well-tolerated antidepressant in elderly patients. Although its mechanism of action remains unclear, bupropion may exert its antidepressant activity via noradrenergic systems (DasGupta, 1998). The principal adverse effects of bupropion include insomnia, agitation and headache. Akin to the Selective Serotonin Reuptake Inhibitors (SSRIs), bupropion can cause weight 
loss, which may be a problem in frail, debilitated, elderly persons (Small, 1991).

\section{- Selective Serotonin Reuptake Inhibitors (SSRIs)}

Fluoxetine is widely prescribed for geriatric patients. However, despite extensive scientific literature describing its efficacy and safety, there is little published data describing the pharmacokinetics of this drug in the elderly. However, Ferguson and Hill (2006) performed a study of the plasma concentration of fluoxetine and norfluoxetine in such subjects, and observed a higher concentration than previously reported in the literature, due to the longer elimination half-life in the elderly. Thus, these high levels of fluoxetine in the plasma of elderly patients may lead to toxic effects (Ferguson, Hill, 2006), producing excessive central nervous system stimulation, sleep disturbances and increasing agitation (Fick et al., 2003). The efficacy of paroxetine seems to be comparable to other SSRIs in the treatment of approved indications, although treatment with paroxetine induces more sedation, constipation, sexual dysfunction, discontinuation syndrome and weight gain than other SSRIs (Marks et al.., 2008). Sertraline and citalopram are drugs recommended for depressive elderly patients, because there are fewer side effects (Gareri et al., 1998).

\section{- Monoamine Oxidase Inhibitors (MAOIs)}

Although MAOIs are effective agents for major depression, for the depressive phase of bipolar disorder and for "atypical" depression (i.e., depression with hypersomnia and hyperphagia), they are currently not first line drugs and are infrequently used in elderly patients (DasGupta, 1998).

Drugs inhibiting mitochondrial monoamine oxidase have mild antimuscarinic effects. Nevertheless, they may provoke orthostatic hypotension, insomnia, tremors, mental tension and especially severe hypertensive crises, which could potentially lead to death. This could occur following the ingestion of food containing tyramine, tryptophan and tyrosine (Gareri et al., 1998).

\section{- Mood stabilizing drugs}

Mood stabilizing drugs are widely used to prevent the recurrence of depression and for preventing and treating bipolar illness. They include lithium, the anticonvulsants, carbamazepine and valproic acid (Gareri et al., 2000).

\section{Lithium}

Lithium, which is used in the treatment of bipolar illness and in mania, requires plasma concentration monitoring, because it is metabolized and excreted by the kidneys, and there is also renal function decline with age. Thus, the dosage should be reduced in older persons (Hewick et al., 1977).

Moreover, elderly patients who have concomitant physical disease and require the administration of a variety of medications that could disrupt the water and electrolyte balance may present potentially hazardous fluctuations in their lithium concentrations (De Angelis, 1990). Moreover, lithium can interfere with renal sodium excretion, modify thyroid function and cause heart conduction disturbances. Therefore careful monitoring of this drug is required. Rare side effects are nausea, diarrhea, abdominal pain and weakness. The concomitant administration of a thiazide diuretic should be avoided, or at least followed by a decrease in the lithium dosage, since its excretion may be reduced (Gareri et al., 2000).

\section{Carbamazepine}

Carbamazepine is an antiepileptic drug, but in psychiatry clinics it is used in the treatment of acute mania when lithium is unsuccessful or poorly tolerated, and can also be used in bipolar manic-depressive patients and added to tricyclic antidepressants in all patients with therapy-resistant unipolar depression. Carbamazepine elimination is dose-dependent and varies greatly with age. Its main side effects are nausea, dizziness, ataxia, visual disturbances and in rare cases, aplastic anemia. It is a potent enzyme inducer, so it may reduce the levels of other drugs such as haloperidol, theophylline, warfarin and steroids, and for chronic administration, it can even induce the enzymes responsible for its own metabolism, such as CYP3A4, cytochrome P450 (CYP), the enzyme located in the enterocyte and/or the drug transporter protein that pumps the drug out into the intestinal lumen: the multiple resistance protein (MRP2) (Leppik, 1992; Gareri et al., 2000; Fagiolino et al., 2006). Due to these factors, carbamazepine should be used with caution, especially in elderly patients.

\section{- Drug treatment of epilepsy}

The majority of older patients require lower doses of antiepileptic drugs (AEDs) than younger adults, however higher valproic acid (VPA) doses may be required in patients taking drugs which induce hepatic microsomal enzymes. Once-daily dosing of controlled-release preparations can help to improve compliance and may render some elderly people seizure free (Stephen, 2003).

It is known that the elderly are generally more susceptible to the adverse effects of AEDs than younger adults, since dose-dependent and idiosyncratic reactions 
may be more frequent. The most common side effects of VPA are nausea, vomiting, abdominal pain and heartburn. To avoid such side effects a slow tapering of the dosage is necessary, especially in the elderly. A severe side effect, due to its idiosyncratic toxicity, is hepatotoxicity (Gareri et al., 2000).

VPA is a long established AED, and its broad spectrum of action and dosing schedule are favorable properties for its use in older people. Total VPA clearance is similar in young and elderly subjects. The drug does not induce the metabolism of hepatic enzymes, but can act as a metabolic inhibitor (Stephen, 2003). In elderly adults with partial-onset seizures, gabapentin and lamotrigine have shown efficacy and effectiveness as initial monotherapy (Glauser et al., 2006).

\section{- Antipsychotic drugs}

Antipsychotics are widely used in geriatric psychiatric disorders. The first-line recommendation for agitated dementia with delusions is an antipsychotic drug alone, but they could also be considering adding a mood stabilizer. Risperidone was first line followed by quetiapine, and olanzapine as high second-line options. While for older patients with delusional disorder, an antipsychotic was the only treatment recommended. For treatment of geriatric psychotic major depression, an antipsychotic plus an antidepressant is recommended (Alexopoulos et al., 2004).

It is important to know that if a combination of antidepressants and antipsychotics is necessary, it would be much more cautious to use selective serotonin reuptake inhibitors that are more potent inhibitors of the CYP 450 enzymes (i.e., fluoxetine and paroxetine), together with nefazodone, TCAs and monoamine oxidase inhibitors. Extra monitoring is recommended when combining antipsychotic drugs with any of the following: lithium, carbamazepine, lamotrigine and valproate (except aripiprazole and risperidone plus valproate) or with codeine, phenytoin or tramadol (Alexopoulos et al., 2004).

\section{Cardiovascular drugs}

\section{Antihypertensive drugs}

Hypertension is a major risk factor for cardiovascular disease, stroke and renal disease. It is important to highlight the high prevalence of hypertension in elderly, as it increases markedly with aging, affecting about $65 \%$ of the population beyond the seventh decade of life (Borzecki et al., 2003).

The pathophysiology of hypertension in the elderly is a multifactorial disease (Cooney, Pascuzzi, 2009). Ac- cording to Guidelines for treatment of hypertension in the elderly, this pathology is characterized by an increase in total peripheral vascular resistance, decreased compliance of the large and middle arteries, tendency towards a decrease in cardiac output and circulating blood volume, increased lability of blood pressure due to age-related baroreceptor function, decreased blood flow and dysfunction of the auto-regulation in important target-organs such as the brain, heart and kidney. These changes can make treating hypertension in the elderly challenging, putting patients at increased risk of developing adverse events and complications with antihypertensive medications. Therefore, it is important to treat hypertension in the elderly with special attention (Ogihara et al., 2003).

All antihypertensive drugs may predispose older patients to the development of symptomatic orthostatic hypotension and postprandial hypotension, as well as falls and syncope. The adverse effects depend on the antihypertensive drugs administered, the doses used, the co-morbidities present in the older patients taking these drugs, and the drug-drug interactions (Aronow, 2009).

Beta-blockers, especially propanolol, have been reported to cause delirium (Alagiakrishnan, Wiens, 2004). Calcium antagonists cause many adverse reactions, verapamil causes mainly bradyarrhythmias and obstipation, and nifedipine causes mainly hypotension, peripheral edema, skin rash, and tachycardia (Pahor et al., 1996).

\section{Diuretics}

Diuretic therapy requires extra caution, because elderly patients are more susceptible to fluid electrolyte disorders, hypokalemia, hyponatremia, hypomagnesemia and volume depletion (Williams, Lowenthal, 1992). In addition, diuretics can induce delirium by dehydration and electrolyte disturbances (Alagiakrishnan, Wiens, 2004).

Age-dependent changes in renal tubular function can alter the effect of drugs in the kidney, for instance, the effects occurring in the kidney caused by organic acid diuretics, such as furosemide and bumetanide. Likewise, the tubular renal clearance of bumetanide was lower in older healthy outpatients compared to younger volunteers, due to reduced renal tubular secretion in the older group. Thus, high levels of diuretics in the plasma of elderly people may lead to some toxic effects (Cusack, 2004).

Spironolactone alone may not be sufficient to control blood pressure, especially in older patients. All other classes of antihypertensive agents can be used in combination with this diuretic. If spironolactone is used with the angiotensin-converting enzyme inhibitor and angiotensin receptor blocker, this increases the risk of hyperkalemia (Gaddam et al., 2009). 


\section{Digitalis}

In the elderly, because of decreased renal clearance, even normal doses of digoxin can accumulate and cause toxicity and delirium (Alagiakrishnan, Wiens, 2004), therefore the dose should not exceed $0.125 \mathrm{mg}$ /day except when treating atrial arrhythmias (Fick et al., 2003). It was postulated that the apparent sensitivity of elderly patients to digitalis might be related, in part, to the decreased renal excretion, because creatinine clearance is decreased in the elderly and it is known that digoxin is predominantly excreted by the kidneys. Evidence shows that the use of the same dose of digoxin in elderly and young adult subjects resulted in blood concentrations nearly twice as high in the elderly, evidencing the vulnerability of the elderly to poisoning by this drug (Ewy et al.,1969).

In another study performed by Dall (1970) involving elderly patients on maintenance digoxin doses, about $34 \%$, had to stop the treatment because of toxic effects, such as arrhythmias, nausea and vomiting, mental confusion, refractory cardiac failure, gynaecomastia and xanthopsia.

\section{Statins}

Among elderly patients, statins are generally well tolerated and adverse events are usually mild and transient. Also, the general population's tolerance to the drugs rosuvastatin, atorvastatin, simvastatin and pravastatin was similar across treatments (Jones et al., 2003).

The safety of atorvastatin and simvastatin was similar in patients aged $<65$ and $>65$ years with stable coronary disease. However, when statins are used, the levels of creatine kinase (CK), and transaminases (AST and ALT) must be monitored, because these drugs can cause rhabdomyolysis and myopathy in both elderly and young people (Tikkanen et al., 2009). Roberts, Guallar and Rodriguez (2007) found musculoskeletal symptoms together with abnormalities in $\mathrm{CK}$ and liver enzymes to be the most commonly reported adverse events in elderly patients.

Deedwania et al. (2007) carried out a comparative study between pravastatin and atorvastatin, and observed that the serious adverse events were similar with both treatments, except for the test for liver function abnormalities, which were more frequent in the atorvastatin group. However, the liver enzyme levels returned to normal for all patients on repeat testing during the follow-up or after discontinuation of the medication. In both studies, no cases of rhabdomyolysis were detected (Deedwania et al., 2007), but older patients may be more susceptible to the adverse effects of these drugs (Tikkanen et al., 2009).

\section{Antiplatelet drugs}

Strokes and transient ischemic attacks become more common with advancing age and their prognosis worsens. Due to the increase in the number of elderly subjects in most western societies, atherothrombotic cerebrovascular disease is a significant health problem. It is therefore important to find effective treatments for both primary and secondary prevention (Sivenius, Riekkinen, Laakso, 1995).

Antiplatelet drugs are administered to the elderly in the primary prevention of myocardial infarction, and to treat cerebral transient ischemic attacks and ischemic strokes. Aspirin has been combined with ticlopidine to prevent thrombosis of coronary artery stents. A few studies have suggested that bleeding complications with anti platelet agents may be more severe in the elderly.

To treatment this disorder there are other anti platelet drugs, such as clopidogrel and abciximab (Green, Padrozik, 2000). A study carried out by Bagur et al. (2009) compared bleeding and ischemic outcomes after transradial percutaneous coronary intervention and maximal antiplatelet therapy in patients aged $<70$ or $>70$ years old, with acute coronary syndromes. All patients received aspirin and clopidogrel before catheterization, followed by abciximab at the time of the percutaneous coronary intervention. The authors concluded that, under the conditions tested, older patients remained more prone to gastrointestinal bleeding and local hematoma compared to younger patients, and preventive measures need to be further investigated (Bagur et al., 2009).

Abciximab, the most potent GPIIb/IIIa inhibitor, was also studied by Ndrepepa et al. (2006). These authors showed that the efficacy of the drug was age-dependent, with no effect in patients $>70$ years of age, which again illustrates the need to carefully evaluate the use of drugs in elderly patients.

\section{Oral erectile dysfunction drugs}

Sexual function tends to decline with aging, which is often associated with a higher prevalence of sexual problems, including erectile dysfunction and loss of libido. Particular care was taken to assess the cardiovascular safety of oral drugs for erectile dysfunction in this subset of patients, who often have multiple cardiovascular risk factors which contribute to a clinical complication (Salonia et al., 2005).

Sildenafil citrate is an orally active inhibitor of phosphodiesterase type 5, and it is used as treatment for male erectile dysfunction. This drug is cleared almost exclusively by hepatic metabolism and its primary metabolite is N-desmethyl metabolite - UK 103,320 (Muirhead et al., 2002). 
A study performed by Muirhead et al. (2002) showed that the pharmacokinetics of sildenafil was affected by age. Plasma concentrations of sildenafil and UK 103,320 rose rapidly in the young and elderly subjects, but in young men, the plasma sildenafil concentrations decreased to nondetectable concentrations by approximately the $16 \mathrm{~h}$ post dose, while the concentrations remained detectable for up to $36 \mathrm{~h}$ in the elderly men. Concentrations of UK 103,320 were detectable for up to $24 \mathrm{~h}$ in the younger subjects and $36 \mathrm{~h}$ in the elderly subjects. Thus elderly patients are more vulnerable to the toxic effects of this drug, including headaches, flushing and dyspepsia (Müller et al., 2007).

\section{Antidiabetic drugs}

Diabetes is an important health condition in the aging population. At least $20 \%$ of all patients over the age of 65 years suffer from diabetes, and this number is expected to grow rapidly in the coming decades (Viljoen, Sinclair, 2009).

The treatment of diabetes in the elderly may lead to serious complications even at relatively low doses. For example, the sulphonylureas, especially the long-acting agents such as chlorpropamide and glibenclamide, can produce life-threatening hypoglycemia. The risk is even higher in frail elderly patients with impaired renal function (Chan, 2006).

Rosiglitazone also showed an increased risk of congestive heart failure, acute myocardial infarction and mortality compared with other combined oral hypoglycemic agent treatments, while pioglitazone does not have these complications. However, both rosiglitazone and pioglitazone drugs have been shown to increase bone loss in elderly women but not in men (Lipscombe et al., 2007). In addition, rosiglitazone increased the risk of bone fractures in the elderly (Kahn et al., 2006).

\section{Antihistamine drugs}

Sedation related to first-generation antihistamine use, such as chlorpheniramine, dexchorpheniramine, diphenhydramine, hydroxyzine and promethazine, has been shown to compromise driving performance and decrease the ability to handle tasks that require a high degree of alertness or concentration, due to the drowsiness caused by these drugs (McCue, 1996).

Second-generation antihistamines are less likely to produce sedation. Loratadine, cetirizine and fexofenadine are the most commonly prescribed second-generation antihistamines. At recommended doses, loratadine is not associated with performance impairment, whereas cetirizine at the recommended doses has been shown to impair performance and cognition, although to a much lesser degree than the older antihistamines. Fexofenadine is nonsedating even at very high doses, and psychomotor and driving tests have reinforced these findings. Loratadine, cetrizine, and fexofenadine all have good safety records in specific populations, including in elderly patients (Edward, Philpot, 2000).

\section{Antibiotics}

As mentioned previously, kidney function declines with aging, and thus the rate of elimination of drugs excreted mainly by this organ is generally reduced in the elderly. Antibiotics form an important group of drugs cleared largely by the kidney. Aztreonam, meropenem, ceftazidime and ofloxacin are examples of antibiotics that need to be administered in reduced doses in the elderly, in order to avoid toxic effects (Meyers, Wilkinson, 1989).

In addition, the reduced clearance of active metabolites from certain drugs may enhance the therapeutic effect but increase the risk of toxicity, particularly in very elderly patients with more probable renal impairment. Examples include $\mathrm{N}$-acetyl-procainamide, the active metabolite of procainamide; morphine-6-glucuronide, the active metabolite of morphine, and normeperidine (norpethidine), the metabolite of meperidine (pethidine) (Cusack, 2004).

In addition, nitrofurantoin (NFT) shows the potential for renal impairment in elderly patients (Fick et al., 2003). NFT is highly effective against most strains of E. coli and the enterococci, but has poor activity against most Proteus, Pseudomonas, Enterobacter and Klebsiella spp. The most common reactions to NFT are pulmonary (pneumonitis, vasculitis, pleuritis) and allergic (cutaneous rashes, fever, anaphylaxis) disorders. Pneumonitis is characterized by fever, chills, cough, chest pain and dyspnea, and chest radiography may reveal infiltrates. Eosinophilia is also common, but the symptoms are usually resolved within hours of discontinuing the drug. Elderly patients are most at risk with respect to this complication and pulmonary fibrosis may result from chronic usage (Graeme, Pollack, 1996). It is important to note that, especially in older women, treatment with NFT can have several adverse effects, including nausea and vomiting and allergic, pulmonary, hepatic, neurological and haematological reactions (Nys et al., 2006).

In general, the antibiotics prescribed for the treatment of urinary tract infections, specifically those including trimethoprim/sulfamethoxazole, fluoroquinolones, nitrofurantoin, amoxicillin, cephalosporins and amino- 
glycosides, are all cleared renally. Consequently, a dosage reduction is recommended in patients with reduced renal clearance (Takahashi et al., 2004).

\section{Anti-inflammatory drugs}

Non-steroidal anti-inflammatory drugs (NSAIDs) have an increased risk of causing hyperkalemia, renal failure and death from gastrointestinal hemorrhage (Williams, Lowenthal, 1992). In general, the risk of hyperkalemia is increased in patients with chronic kidney disease, including the elderly and patients with diabetes (Gaddam et al., 2009).

The cyclo-oxygenase (COX)-2 inhibitors are as effective as standard NSAIDs for the relief of pain and for improving function in elderly patients with osteoarthritis and rheumatoid arthritis. Gastroduodenal disorders are the most frequently reported serious adverse effects of NSAI-s, and occur more frequently in the elderly. Thus, COX-2 inhibitors are an alternative to standard NSAIDs in this age group but are not appropriate for many patients with cardiovascular and renal disease. The adverse reaction profile of the COX-2 inhibitors confirmed the role of the COX-2 enzyme in renal function, salt and water homeostasis and the vascular endothelium. Similar to standard NSAIDs, COX-2 inhibitors can cause renal failure, hypertension and the exacerbation of cardiac failure, and it should be noted that these disorders are dose related. Thus, there are good reasons to avoid high doses of COX-2 inhibitors in the elderly. COX-2 inhibitors have a thrombotic potential, especially at high doses and when their use is prolonged, further limiting the extent to which they can be used in the elderly (Savage, 2005).

Griffin et al. (1991) compared the relative risk of peptic ulcers or gastrointestinal hemorrhage in current elderly users of five different NSAIDs, and showed a significantly greater risk in users of tolmetin, naproxen, piroxicam, and meclofenamate than in users of ibuprofen.

Salicylates are the most frequently used over-thecounter (OTC) drug, and also the most common OTC drug contributing to morbidity and mortality (Gittelman, 1993). Common in elderly, chronic salicylate intoxication may occur even at therapeutic dosages. Older adults are more susceptible to salicylism because they frequently take a lot of drugs, favoring interactions, and have reduced liver and kidney function (which decreases the metabolism and excretion of salicylates), and have a variety of generalized aches and pains that they self-treat with salicylate-containing drugs (Courts, 1996).

Toxicity in the elderly can also be high due to inadvertent overdosage (Durnas, Cusack, 1992). Salicylate toxicity is often overlooked as a cause of confusion in elderly patients and tends to go undiagnosed, leading to increased morbidity and even death (Courts, 1996).

\section{Chemotherapeutic agents}

The increasing number of elderly people in the world population has led to a parallel increase in the number of older cancer patients (Lonardi, 2007). There is much discussion concerning chemotherapy in elderly patients. The data on chemotherapy tolerance in older patients is conflicting, but there are physiological reasons that support the presence of an increased risk of toxicity in the elderly. Age-related changes may, in fact, influence the safety of cytotoxic agents at three levels: pharmacodynamics, pharmacokinetics and tolerance of normal tissues (Biganzoli et al., 2009).

Complications of chemotherapy such as mucositis, anemia, neutropenia, bleeding, cardiac toxicity and neurotoxicity are more frequently observed in the elderly, and may affect individual functional independence (Syrigos, Karapanagiotou, Harrington, 2005). In addition, chemotherapy and most of the agents used to prevent its toxicity, interfere with cognition, balance, vision, continence and mood. Moreover, polypharmacy may lead to interactions with cytotoxic chemotherapeutic agents. All of these conditions may increase the risk of chemotherapy in the elderly (Syrigos et al., 2009).

Taxanes are effective agents in several types of cancer, and docetaxel is the standard taxane. In a randomized phase II trial, elderly metastatic breast cancer patients who took docetaxel presented a higher incidence of stomatitis, neutropenia, and neurotoxicity (Biganzoli et al., 2009).

\section{Antiulcer drugs}

In general, proton pump inhibitors are considered safe and effective drugs in the elderly (Zarowitz, 2009). However, patients who took them for more than 1 year were found to be at increased risk for hip fractures, and it was observed that this effect is dose-related (Yang et $a l ., 2006)$. It is possible that this is due to reduced calcium absorption. Dosage adjustment of the proton pump inhibitors in patients with renal impairment is not necessary, but in patients with hepatic impairment the dosage of pantoprazole and rabeprazole should be decreased (Zarowitz, 2009).

Cimetidine is associated with more clinically important drug interactions than the other histamine-2 antagonists and this medicine can cause several adverse effects, such as bradycardia, arrhythmias, confusion, depression, 
thrombocytopenia, neutropenia, and gynecomastia. For these reasons, cimetidine is not recommended for use in older people. Famotidine and ranitidine can cause impotence, and ranitidine may contribute to cognitive decline, because of their significant anticholinergic properties. Therefore, famotidine and other proton pump inhibitors that present less anticholinergic properties than ranitidine, are preferable in order to avoid these effects in elderly patients (Zarowitz, 2009).

\section{FINAL CONSIDERATIONS}

The pharmacologic treatment of diseases in elderly patients is a great challenge for manifold reasons. Firstly, age influences drug absorption due to various factors such as rise in gastric $\mathrm{pH}$, reduction in gastrointestinal motility and reduction in splanchnic blood flow. Secondly, reduced lean body mass and increased body fat result in higher concentrations of drugs such as lithium that are distributed in the body fluids, increasing the distribution and prolonging the half-life elimination of fat-soluble drugs, such as benzodiazepines. Thirdly, the metabolite clearance of hepatic and renal eliminated drugs may decrease with age, resulting in slower drug clearance. Lastly, the presence of medical illness and increase in age may result in pharmacodynamic changes. Finally, there are many drugs that are contraindicated for the elderly, and therefore much caution is required to treat them. All health professionals should be aware of the changes occurring in elderly individuals, and those prescribing drugs should always take the changes occurring in drug pharmacokinetics and pharmacodynamics during aging into consideration, in order to avoid compromising the health of the elderly through inappropriate prescriptions.

Pharmacists are also important professionals who play a key role in avoiding this problem. The medicines should always be dispensed by a pharmacist, who can give orientation to the patient and identify possible contraindications for the elderly, considering the particularities and needs of each individual. Through this approach, pharmacists can contribute toward more rational use of drugs by elderly patients.

\section{ACKNOWLEDGEMENT}

We would like to thank FAPESP, CNPq and CAPES for the financial support. We also thank the authors of the articles used for this review.

\section{REFERENCES}

ALAGIAKRISHNAN, K.; WIENS, C.A. An approach to drug induced delirium in the elderly. Postgrad. Med. J., v.80, n. 945, p.388-393, 2004.

ALEXOPOULOS, G.S.; STREIM, J., CARPENTER, D., DOCHERTY, J.P. Using antipsychotic agents in older patients: Introduction: Methods, Commentary, and Summary. J. Clin. Psychiatry., v. 65, n.2, p. 5-99, 2004.

APARASU, R.R; MORT, J.R. Prevalence, correlates, and associated outcomes of potentially inappropriate psychotropic use in the community-dwelling elderly. Am. J. Geriatr. Pharmacother., v.2, n.2, p.102-111, 2004.

ARONOW, W.S. Treating hypertension in older adults: safety considerations. Drug Saf., v.32, n.2, p.111-118, 2009.

BAGUR, R.; BERTRAND, O.F.; CABAU, J.R.; RINFRET, S.; LAROSE, E.; MARCOS, H.T.; GLEETON, O.; NGUYEN, C.M.; ROY, L.; COSTEROUSSE, O.; LAROCHELLIERE, R.D. Comparison of outcomes in patients $>70$ years versus $<70$ years after transradial coronary stenting with maximal antiplatelet therapy for acute coronary syndrome. Am. $J$. Cardiol., v.104, n.5, p.624-629, 2009.

BALDUCCI, L.; BEGHE, C. Cancer and age in the USA. Crit. Rev. Oncol. Hematol., v.37, n.2, p.137-145, 2001.

BIGANZOLI, L.; LICITRA, S.; MORETTI, E.; PESTRIN, M.; ZAFARANA, E.; DI LEO, A. Taxanes in the elderly: Can we gain as much and be less toxic? Crit. Rev. Oncol. Hematol., v.70, n.3, p.262-271, 2009.

BLAZER, D.; HYBELS, C.; SIMONSICK, E.; HANLON, J. T. Sedative, hypnotic, and antianxiety medication use in an aging cohort over ten years: a racial comparison. J. Am. Geriatr. Soc., v.48, n.9, p.1073-1079, 2000.

BORZECKI, A.M.; WONG, A.T.; HICKEY, E.C.; ASH, A.S.; BERLOWITZ, D.R. Hypertension control: how well are we doing? Arch. Intern. Med., v.163, n.22, p.2705-2711, 2003.

BROWN, A.S.; ROSEN J. Lithium-induced delirium with therapeutic serum lithium levels: a case report. J. Geriatr. Psychiatry Neurol., v.5, n.1, p.53-55, 1992. 
CASTLEDEN, C. M.; PICKLES, H. Suspected adverse drug reactions in elderly patients reported to the Committee on Safety of Medicines. Br. J. Clin. Pharmac., v.26, n.4, p.347-353, 1988.

CHAN, T.Y.K. Prevention of medication error and unintentional drug poisoning in the elderly. Hong Kong Med. J., v.12, n. 5, p.332-333, 2006.

COONEY, D.; PASCUZZI, K. Polypharmacy in the elderly: focus on drug interactions and adherence in hypertension. Clin. Geriatr. Med., v.25, n.2, p.221-233, 2009.

CORRER, C.J.; PONTAROLO, R.; FERREIRA, L.C.; BAPTISTAO, S.A.O. Riscos de problemas relacionados com medicamentos em pacientes de uma instituição geriátrica. Rev. Bras. Cienc. Farm., v.43, n.1, p.55-62, 2007.

COURTS, N.F. Salicylism in the elderly: "a little aspirin never hurt anybody!" your patients may think that aspirin is completely safe. Do you? Geriatr. Nurs., v.17, n.2, p.5559, 1996.

CUSACK, B.J. Pharmacokinetics in Older Persons. Am. J. Geriatr. Pharmacother., v.2, n.4, p.274-302, 2004.

DALL, J.L.C. Maintenance digoxin in elderly patients. $\mathrm{Br}$. Med. $J .$, v.2, p.705-706, 1970.

DASGUPTA, K. Treatment of depression in elderly patients: recent advances. Arch. Fam. Med., v.7, n.3, p.274-280, 1998.

DEANGELIS, L. Lithium treatment and the geriatric population. Int. J. Clin. Pharmacol., v.28, n.9, p.394-398, 1990.

DEEDWANIA, P.; STONE, P.H.; MERZ, N.B.; COSINAGUILAR, J.; KOYLAN, N.; LUO, D.; OUYANG, P.; PIOTROWICZ, R.; SCHENCK-GUSTAFSSON, K.; SELLIER, P.; STEIN, J.H.; THOMPSON, P.L.; TZIVONI, D. Effects of intensive versus moderate lipid-lowering therapy on myocardial ischemia in older patients with coronary heart disease. Circulation, v.115, p.700-707, 2007.

DURNAS C.; CUSACK B.J. Salicylate intoxication in the elderly. Recognition and recommendations on how to prevent it. Drugs Aging, v.2, n.1, p.20-34, 1992.

EDWARD, E.; PHILPOT, M.D. Safety of second generation antihistamines. Allergy Asthma Proc., v.21, n.1, p.15-20, 2000 .
EWY, G.A.; KAPADIA, G.G.; YAO, L.; LULLIN, M.; MARCUS, F.I. Digoxin metabolism in the elderly. Circulation, v.39, p.449-453, 1969.

FAGIOLINO, P.; VAZQUEZ, M.; OLANO, I.; DELFINO, A. Systemic and presystemic conversion of carbamazepine to carbamazepine-10,11-epoxide during long term treatment. J. Epilepsy Clin. Neurophysiol.,v.12, n.1, p.13-16, 2006.

FERGUSON, J.M.; HILL, H. Pharmacokinetics of fluoxetine in elderly men and women. Gerontology, v.52, n.1, p.4550, 2006.

FICK, D.M.; COOPER, J.W.; WADE, W.E.; WALLER, J.L.; MACLEAN, J.R.; BEERS, M.H. Updating the Beers criteria for potentially inappropriate medication use in older adults: results of a US consensus panel of experts. Arch. Intern. Med., v.163, n.22, p.2716-2724, 2003.

FURLANUT, M.; BENETELLO, P. The pharmacokinetics of tricyclic antidepressant drugs in the elderly. Pharmacol. Res., v.22, n.1, p.15-25, 1990.

GADDAM, K.K.; PIMENTA, E.; HUSAIN, S.; CALHOUN, D.A. Aldosterone and Cardiovascular Disease. Curr. Probl. Cardiol., v.34, n.10, p.51-84, 2009.

GALEOTTA, G.; PAOLETTI, V.; MAMMARELLA, A.; FALASCHI, R. La terapia farmacologica nel paziente anziano. Clin. Ter., v.135, n.3, p.181-192, 1990.

GARERI, P.; STILO, G., BEVACQUA, I.; MATTACE, R.; FERRERI, G.; DE SARRO, G. Review: Antidepressant Drugs in the Elderly. Gen. Pharmac., v.30, n.4, p.465-475, 1998.

GARERI, P.; FALCONI, U.; FAZIO, P.D.; SARRO, G.D. Conventional and new antidepressant drugs in the elderly. Prog. Neurobiol., v.61, n.4, p.353-396, 2000.

GITTELMAN, D.K. Chronic salicylate intoxication. South Med. J., v.86, n.6, p.683-685, 1993.

GLAUSER, T.; BEN-MENACHEM, E.; BOURGEOIS, B.; CNAAN, A.; CHADWICK, D.; GUERREIRO, C.; KALVIAINEN, R.; MATTSON, R.; PERUCCA, E.; TOMSON, T. ILAE Treatment guidelines: evidence-based analysis of antiepileptic drug efficacy and effectiveness as initial monotherapy for epileptic seizures and syndromes. Epilepsia, v.47, n.7, p.1094-1120, 2006. 
GRAEME, K.A.; POLLACK Jr., C.V. Antibiotic use in the emergency department. II. The aminoglycosides, macrolides, tetracyclines, sulfa drugs, and urinary antiseptics. J. Emerg. Med., v.14, n.3, p.361-371, 1996.

GREEN, D.; PADROZIK, P. Key references: antiplatelet drugs in the elderly. J. Thromb.Thrombolysis, v.9, p.115-116, 2000 .

GREENBLATT, D.J.; SELLERS, E.M.; SHADER, R.I. Drug disposition in old age. N. Engl. J. Med., v.306, n.18, p.10811088, 1982.

GREENBLATT, D.J.; HARMATZ, J.S.; SHAPIRO, L.; ENGLEHARDT, N.; GOUTHRO, T.A.; SHADER, R.I. Sensitivity to triazolam in the elderly. N. Engl. J. Med., v.324, n.24, p.1691-1698, 1991.

GRIFFIN, M.R.; PIPER, J.M.; DAUGHERTY, J.R.; SNOWDEN, M.; RAY, W.A. Nonsteroidal anti-inflammatory drug use and increased risk for peptic ulcer disease in elderly persons. Ann. Intern. Med., v.114, n.4, p.256-263, 1991.

HALARIS, A. Antidepressant drug therapy in the elderly: enhancing safety and compliance. Int. J. Psychiatry Med., v.16, n.1, p.1-19, 1987.

HANLON, J.T.; HORNER, R.D.; SCHMADER, K.E.; FILLENBAUM, G.G.; LEWIS, I.K.; WALL JUNIOR, W.E.; LANDERMAN, L.R.; PIEPER, C.F.; BLAZER, D.G.; COHEN, H.J. Benzodiazepine use and cognitive function among community dwelling elderly. Clin. Pharmacol. Ther., v.64, n.6, p.684-692, 1998.

HARDY, S.E. Methylphenidate for the treatment of depressive symptoms, including fatigue and apathy, in medically ill older adults and terminally ill adults. Am. J. Geriatr. Pharmacother., v.7, n.1, p.34-59, 2009.

HARIA, M.; FITTON, A.; MCTAVISH, D. Trazodone. A review of its pharmacology, therapeutic use in depression and therapeutic potential in other disorders. Drugs Aging, v.4, n.4, p.331-355, 1994.

HEMMELGARN, B.; SUISSA, S.; HUANG, A. Benzodiazepine use and the risk of motor vehicle crash in the elderly. JAMA, v.278, n.1, p.27-31, 1997.

HEWICK D.S., NEWBURY P., HOPWOOD S., NAYLOR G., MOODY J. Age as a factor affecting lithium therapy. Br. J. Clin. Pharmacol., v.4, n.2, p.201-205,1977.
JEFFERSON, J.W. A review of the cardiovascular effects and toxicity of tricyclic antidepressants. Psychosom. Med., v.37, n.2, p.160-179, 1975.

JONES, P.H.; DAVIDSON, M.H.; STEIN, E.A.; BAYS, H.E.; MCKENNEY, J.M.; MILLER, E.; CAIN, V.A.; BLASETTO, J.W. Comparison of the Efficacy and safety of Rosuvastatin versus Atorvastatin, Simvastatin, and Pravastatin across doses (STELLAR Trial). Am. J. Cardiol., v.92, n.2, p.152-160, 2003.

KAHN, S.E.; HAFFNER, S.M.; HEISE, M.A.; HERMAN, W.H.; HOLMAN, R.R.; JONES, N.P.; KRAVITZ, B.G.; LACHIN, J.M.; O’NEILL, M.C.; ZINMAN, B.; KIRBY, M.; DENIHAN, A.; BRUCE, I.; RADIC, A.; COAKLEY, D.; LAWLOR, B. A. Benzodiazepine use among the elderly in the community. Int. J. Geriatr. Psychiatry, v.14, n.4, p.280-284, 1999.

KOENIG, H.G. Depressive disorders in older medical inpatients. Am. Fam. Physician., v.44, n.4, p.1243-1250, 1991.

KOTLYAR, M.; DYSKEN, M.; ADSON, D.E. Update on Drug-Induced Depression in the Elderly. Am. J. Geriatr. Pharmacother., v.3, n.4, p.288-300, 2005.

KYLE, U.G.; GENTON, L.; SLOSMAN, D.O.; PICHARD, C. Fat-free and fat mass percentiles in 5225 healthy subjects aged 15 to 98 years. Nutrition, v.17, n.7, p.534-541, 2001.

LEPPIK, I.E. Metabolism of antiepileptic medication: newborn to elderly. Epilepsia, v.33, suppl.4, p.S32-S40, 1992.

LIPSCOMBE, L.L.; GOMES, T.; LÉVESQUE, L.E.; HUX, J.E.; JUURLINK, D.N.; ALTER, D.A. Thiazolidinediones and cardiovascular outcomes in older patients with diabetes. JAMA, v.298, n.22, p.2634-2643, 2007.

LONARDI, S.; BORTOLAMI, A.; STEFANI, M.; MONFARDINI, S. Oral anticancer drugs in the elderly: an overview. Drugs Aging, v.24, n.5, p.395-410, 2007.

MARKS., D.M.; PARK, M.H.; HAM., B.J.; HAN., C.; PATKAR ., A.A.; MASAND, P.S.; PAE., C.U. Paroxetine: safety and tolerability issues. Expert. Opin. Drug. Saf., v.7, n.6, p.783794, 2008.

McANDREWS, M.P.; WEISS, R.T.; SANDOR, P.; TAYLOR, A.; CARLEN, P.L.; SHAPIRO, C.M. Cognitive effects of long-term benzodiazepine use in older adults. Hum. Psychopharmacol., v.18, n.1, p.51-57, 2003. 
McCUE, J.D. Safety of antihistamines in the treatment of allergic rhinitis in elderly patients. Arch. Fam. Med., v.5, n.8, p.464-468, 1996.

MEYERS, B.E.; WILKINSON, P. Clinical pharmacokinetics of antibacterial drugs in the elderly. Implications for selection and dosage. Chin. Pharmacokinet., v.17, n.6, p.385-395, 1989.

MUIRHEAD, G.J.; WILNER, K.; COLBURN, W.; HAUGPIHALE, G.; ROUVIEX, B. The effects of age and renal and hepatic impairment on the pharmacokinetics of sildenafil citrate. Br. J. Clin. Pharmacol., v.53, suppl.1, p.21S-30S, 2002.

MÜLLER, A.; SMITH, L.; PARKER, M.; MULHALL, J.P. Analysis of the efficacy and safety of sildenafil citrate in the geriatric population. BJU Int., v.100, n.1, p.117-121, 2007.

MULSANT, B.H.; GANGULI, M. Epidemiology and diagnosis of depression in late life. J. Clin. Psychiatry, v.60, suppl.2020, p.9-15, 1999.

NAUGLER, C.T., BRYMER C.; STOLEE, P.; ARCESE Z.A. Development and validation of an improved prescribing in the elderly tool. Can. J. Clin. Pharmacol., v.7, n.2, p.103$107,2000$.

NDREPEPA, G, KASTRATI, A; MEHILLI, J; NEUMANN, F-J; TEN BERG, J; BRUSKINA, O; DOTZER, F; SEYFARTH, M; PACHE, J; DIRSCHINGER, J; ULM, K; BERGER, P.B.; SCHÖMIG, A. Age-dependent effect of abciximab in patients with acute coronary syndromes treated with percutaneous coronary intervention. Circulation., v.114, n.19, p.2040-2046, 2006.

NOBLE, R.E. Drug therapy in the elderly. Metabolism, v.52, suppl.2, p.27-30, 2003.

NOBREGA, O.T.; MELO, G.F.; KARNIKOWSKI, M.G.O. Pattern of drugs prescribed for community-residing middleaged and older adults from the outskirts of Brasília. Rev. Bras. Cienc. Parm., v.41, n.2, p.271-277, 2005.

NYS, S.; MERODEB, T.V.; BARTELDS, A.I.M.; STOBBERINGH, E.E. Antibiotic treatment and resistance of unselected uropathogens in the elderly. Int. J. Antimicrob. Agents, v.27, n.3, p.236-241, 2006.
OGIHARA, T.; HIWADA, K.; MORIMOTO, S.; MATSUOKA, H.; MATSUMOTO, M.; TAKISHITA, S.; SHIMAMOTO, K.; SHIMADA, K.; ABE, I.; OUCHI, Y.; TSUKIYAMA, H.; KATAYAMA, S.; IMAI, Y.; SUZUKI, H.; KOHARA, K.; OKAISHI, K.; MIKAMI, H. Guidelines for treatment of hypertension in the elderly-2002 revised version. Hypertens. Res., v.26, n.1, p.1-36, 2003.

O’MAHONY, M.S.; WOODHOUSE, K.W. Age, environmental factors and drug metabolism. Pharmacol. Ther., v.61, n.1-2, p.279-287, 1994.

PAHOR, M.; MANTO, A.; PEDONE, C.; COROSELLA, L.; GURALNIK, J.M.; CARBONIUN, P. Age and severe adverse drug reactions caused by nifedine and verapamil. J. Clin. Epidemiol., v.49, n.8, p.921-928, 1996.

PARKER, S.L.; TONG, T.; BOLDEN, S.; WINGO, P.A. Cancer statistics. CA Cancer J. Clin., v.47, n.1, p.5-27, 1997.

PATERNITI, S.; MARIE-HÉLÈNE, V.T.; CAROLE, D.; ANNICK, A. Depressive symptoms and cognitive decline in elderly people. Longitudinal study. Br. J. Psychiatry, v.181, p.406-410, 2002.

POSNER, J. Clinical pharmacology - the basics. Surgery, v.27, n.4, p.153-157, 2009.

RAY, W.A.; GRI, M.R.; DOWNEY, W. Benzodiazepines of long and short elimination half-life and the risk of hip fracture. $J A M A$, v.262, n.23, p.3303-3307, 1989.

RICHELSON E. Treatment of acute depression. Psychopharmacology, v.16, n.3, p.461-478, 1993.

RITZ, P.; VELLAS, B. Pharmacokinetics and drug toxicity in elderly patients: a case for geriatric core data in clinical trials. J. Nutr. Health Aging, v.11, n.3, p.261-264, 2007.

ROBERTS, C.G.P.; GUALLAR, E.; RODRIGUEZ, A. Efficacy and safety of statin monotherapy in older adults: a metaanalysis. J. Gerontol. Biol. Med. Sci., v.62, n.8, p.879-87, 2007.

SAFAR, M. Ageing and its effects on the cardiovascular system. Drugs, v.39, suppl.1, p.1-8, 1990. 
SALONIA, A.; BRIGANTI, A.; MONTORSI, P.; MAGA, T.; DEHÒ, F.; ZANNI, G.; MAZZOCCOLI, B.; SUARDI, N.; RIGATTI, P.; MONTORSI, F. Safety and tolerability of oral erectile dysfunction treatments in the elderly. Drugs Aging, v.22, n.4, p.323-338, 2005.

SAVAGE, R. Cyclo-oxygenase-2 inhibitors: when should they be used in the elderly? Drugs Aging, v.22, n.3, p.185-200, 2005.

SCHWEIZER, E.; RICKELS, K. Benzodiazepine dependence and withdrawal: a review of the syndrome and its clinical management. Acta Psychiatr. Scand., v.98, suppl.393, p.95-101, 1998.

SIMON, G.E.; VONKORFF, M.; BARLOW, W.; PABINIAK, C.; WAGNER, E. Predictors of chronic benzodiazepine use in a health maintenance organization sample. J. Clin. Epidemiol., v.49, n.9, p.1067-1073, 1996.

SIVENIUS, J.; RIEKKINEN, P.J.; LAAKSO, M. Antiplatelet treatment in elderly people with transient ischaemic attacks or ischaemic strokes. BMJ, v.310, n.6971, p.25-26, 1995.

SMALL, G. Recognition and treatment of depression in the elderly. J. Clin. Psychiatry, v.52, suppl.6, p.11-22, 1991.

SOOD, A.; BARTON, D.L.; LOPRINZI, C.L. Use of methylphenidate in patients with cancer. Am. J. Hosp. Palliat. Care, v.23, n.1, p.35-40, 2006.

STEPHEN, L.J. Drug treatment of epilepsy in elderly people: focus on valproic acid. Drugs Aging, v.20, n.2, p.141-152, 2003.

S YRIGOS, K.N.; KARAPANAGIOTOU, E.M.; HARRINGTON, K.J. Prostate cancer in the elderly. Anticancer Res., v.25, n.6C, p.4527-4534, 2005.

SYRIGOS, K.N.; KARACHALIOS, D.; KARAPANAGIOTOU, E.M.; NUTTING, C.M.; MANOLOPOULOS, L.; HARRINGTON, K.J. Head and neck cancer in the elderly: An overview on the treatment modalities. Cancer Treat. Rev., v.35, n.3, p.237-245, 2009.

TAKAHASHI, P.; TRANG, N.; CHUTKA, D.; EVANS, J. Antibiotic prescribing and outcomes following treatment of symptomatic urinary tract infections in older women. $J$. Am. Med. Dir. Assoc., v.5, n.2, p.S12-S15, 2004.
TANAKA, E. In vivo age-related changes in hepatic drugoxidizing capacity in humans. J. Clin. Pharm. Ther., v.23, n.4, p.247-255, 1998.

TIKKANEN, M.J.; HOLME, I.; CATER, N.B.; SZAREK, M.; FAERGEMAN, O.; KASTELEIN, J.J.P.; OLSSON, A.G.; LARSEN, M.L.; LINDAHL, C.; PEDERSEN, J.R. Comparison of efficacy and safety of Atorvastatin $(80 \mathrm{mg})$ to Simvastatin (20 to $40 \mathrm{mg}$ ) in patients aged $<65$ versus $>65$ years with coronary heart disease (from the incremental decrease through aggressive lipid lowering [ideal] study). Am. J. Cardiol., v.103, n.1, p.577-582, 2009.

TERI, L.; REIFLER, B.V.; VEITH, R.C.; BARNES, R.; WHITE, E.; McLEAN, P.; Raskind, M. Imipramine in the treatment of depressed Alzheimer's patients: impact on cognition. J. Gerontol., v.46, n.6, p.372-377, 1991.

TINETTI, M.E.; SPEECHLEY, M.; GINTER, S.F. Risk factors for falls among elderly persons living in the community. $N$. Engl. J. Med., v.319, n.26, p.1701-1707, 1988.

TU, K.; MAMDANI, M.M.; HUX, J.E.; TU, J. Progressive trends in the prevalence of benzodiazepine prescribing in older people in Ontario, Canada. J. Am. Geriatr. Soc., v.49, n.10, p.1341-1345, 2001.

TURNHEIM, K. Drug dosage in the elderly. Is it rational? Drugs Aging, v.13, n.5, p.357-379, 1998.

TURNHEIM, K. When drug therapy gets old: pharmacokinetics and pharmacodynamics in the elderly. Exp. Gerontol., v.38, n. 8, p.843-853, 2003.

TURNHEIM, K. Drug therapy in the elderly. Exp. Gerontol., v.39, p.1731-1738, 2004

UCHIDA ,H.; MAMO, D.C. Dosing of antipsychotics in schizophrenia across the life-spectrum. Prog. Neuropsychopharmacol. Biol. Psychiatry, v.33, n.6, p.917920, 2009.

UCHIDA, H.; SUZUKI, T.; MAMO, D.C.; MULSANT, B.H.; KIKUCHI, T.; TAKEUCHI, H.; TOMITA, M.; WATANABE, K.; YAGI, G.; KASHIMA, H. Benzodiazepine and antidepressant use in elderly patients with anxiety disorders: A survey of 796 outpatients in Japan. J. Anxiety Disord., v.23, n.4, p.477-481, 2009. 
VEITH, R.C.; RASKIND, M.A.; CALDWELL, J.H. Cardiovascular effect of tricyclic antidepressants in depressed patients with chronic heart disease. N. Engl. J. Med., v.306, n.16, p.954-959, 1982.

VIBERTI, G. Glycemic durability of rosiglitazone, metformin, or glyburide monotherapy. N. Engl. J. Med., v.355, n.23, p.2427-2443, 2006.

VILJOEN A.; SINCLAIR A. Safety and efficacy of rosiglitazone in the elderly diabetic patient. Vasc. Health Risk Manag., v.5, n.1, p.389-395, 2009.

WILLIAMS, L.; LOWENTHAL, D. Drug therapy in the elderly. South. Med.J., v.85, n.2, p.127-132, 1992.
WORLD HEALTH ORGANIZATION. The uses of epidemiology in the study of the elderly. Geneva, 1984. (Technical Report Series, 706).

YANG, Y.X.; LEWIS, J.D.; EPSTEIN, S.; METZ, D.C. Longterm proton pump inhibitor use and the risk of hip fracture. JAMA, v.296, n.24, p.2947-2953, 2006.

ZAROWITZ, B.J. Pharmacology consideration of commonly used gastrointestinal drugs in the elderly. Gastroenterol. Clin. N. Am., v.38, n.3, p.547-562, 2009.

Received for publication on $17^{\text {th }}$ November 2009. Accepted for publication on $13^{\text {th }}$ April 2010. 